\title{
Attitudes of Turkish teacher candidates towards discussion
}

\author{
Zeynep Cin Şeker a 1 (D) \\ ${ }^{a}$ Ataturk University, Erzurum, 25100, Turkey
}

\section{APA Citation:}

Cin Şeker, Z. (2020). Attitudes of Turkish teacher candidates towards discussion. Journal of Language and Linguistic Studies, 16(2), 9931005.

Submission Date:03/02/2020

Acceptance Date:0/04/2020

\begin{abstract}
In this study, it was aimed to determine the attitudes of Turkish teacher candidates towards discussion skills according to variables of gender, grade, type of high school graduated, and the number of books read in a month. The research sample was determined with the appropriate sampling method. Participants of the study determined by the mentioned sampling method are the students of Atatürk University Kazım Karabekir Education Faculty Turkish Education Department. A total of 253 students, 55 of which were 1st grade, 56 of which were 2 nd grade, 86 of which were 3rd grade, and 56 of which were 4th grade participated in the study. In the research in which the screening model was used, the "Discussion Skill Attitude Scale" developed by Ocak and Karakuş (2015) was used to determine the attitudes of Turkish teacher candidates towards discussion skills. The data obtained were analyzed with the SPSS 22.0 package program. As a result, it was observed that the attitudes of Turkish teacher candidates towards discussion skills did not differ according to gender, class level, and high school of graduation variables, and differed according to the number of books read in favor of those who read 5-6 books in a month. The results of the study were discussed together with the studies examining the attitudes towards the discussion skill. At the same time, the results of the studies examining the attitudes towards critical thinking skills are taken into account in the discussion section since the discussion skill has an important place in the development of critical thinking skills.
\end{abstract}

(C) 2020 JLLS and the Authors - Published by JLLS.

Keywords: discussion skill; Turkish teacher candidates; attitude; basic skills

\section{Introduction}

The ever-changing and developing technology has diversified and facilitated ways of accessing information. Nowadays, it is of great importance to reach correct information and to use it in a functional way rather than just to reach information. This change is also reflected in the education and training process, and therefore, the individual is expected to develop high-level thinking skills such as structuring information reached, critical and creative thinking, analytical thinking, discussion, decision making, and evaluation rather than just to reach information. An individual who has advanced thinking skills and can think critically must have certain characteristics. According to Ferret (1997), an individual who can think critically has the following features:

\footnotetext{
${ }^{1}$ Corresponding author. Tel.: 5548709440

E-mail address: zeynep.seker@atauni.edu.tr
} 
- Constantly asks questions,

- Constantly evaluates expressions,

-Curious,

- Tries to find new solutions for the problems,

- Uses various criteria while analyzing thoughts,

- Examines various views and arguments and compares them with facts,

- Listens carefully to others and gives feedback,

- Knows that critical thinking is a lifelong process,

-Reaches judgments after collecting and analyzing all the data,

- Continuously looks for evidence to support his/her views,

- Does not accept irrelevant and incorrect information (quoted by Tümkaya \& Aybek, 2008, p. 389).

Contemporary teaching approaches give importance to the individual's ability to use, interpret the knowledge acquired, and to construct his / her thoughts by using different views and thoughts. Traditional teaching approaches, in which the information is presented as ready, and the student can only memorize the information, prevent the student from being in the foreground, and taking responsibility in the learning process. Situations that prevent the individual from structuring knowledge and developing higher-level thinking skills can be expressed as follows: Monotony, fear of making mistakes, negativity, inability to think independently, seeing himself/herself as adequate, being perfectionist, acting without thinking, excessive confidence in the teacher, showing dogmatic behavior, excessive lack of confidence towards himself/herself, inability to achieve the goal (Semerci, 2003). Yeşil (2004, p. 196) explained the ways to overcome these obstacles as follows: It is very difficult, even impossible to learn and develop thinking without thinking, criticizing without criticizing, expressing without expressing. An effective way to overcome this impossibility is to use discussion as a method in educational activities. Individuals should be allowed to learn these skills by discussing, living, and observing.

Discussion skills include the ability to analyze, discuss based on data, and justify the information and thought presented. Discussion approaches are effective in developing students' thinking skills and highlevel learning skills such as practice, analysis, synthesis, and evaluation. At the same time, the discussion helps students gain better communication skills, as it allows them to present their ideas clearly and briefly. The method of discussion encourages not only students' communication skills, but also their confidence and motivation to learn, their research, and reflection skills. Discussion as a teaching method allows students to be active in their own learning, which increases their motivation to learn and make the learning process more interesting (Cashin, 2011; Biney, 2018)

Thinking in everyday life involves many actions. Asserting arguments, making determinations, providing evidence, making conclusions, making definitions, bringing clarity, seeking justification for conclusions, identifying, describing, doubting, choosing, showing, grounding, reasoning... All these actions constitute thinking skills. Thinking takes root in human with the language he/she speaks. Humans need language to think. Therefore, we can say that the existence of thought depends on the language. So thought is nothing but a search for expressions that make us take action and make our daily problems solvable (Öner, 2001, p. 434). In this context, it is expected that the language skills should be developed in order for the individual to produce and develop thoughts in order to acquire and develop basic skills.

In the context of Turkish lessons, basic skills aimed to be developed in students were included in the 2006 Turkish Lesson Teaching Curriculum (TLTC) for the first time. These basic skills are determined 
as "Using Turkish correctly, beautifully and effectively, critical thinking, creative thinking, communicating, problem-solving, research, decision making, using information technologies and entrepreneurship" (MEB, 2006, p. 5).

From this point of view, in order to develop critical thinking skills, teachers should prepare activities in the language education process in which students can comment, analyze and evaluate, question what they know, explain the claims they have reached, solve problems, and examine and change their own thoughts when necessary (Kurudayığlu \& Çetin, 2015, p. 5). Paying attention to some points in discussions in the classroom environment supports the development of students' critical thinking skills. Teachers who ask their students high-level questions and want their answers to be supported with evidence, help students gain critical thinking skills and increase their tendency towards critical thinking. Open and supportive classroom environments in which thoughts can be freely expressed and examined, but within a discipline, have positive effects on the acquisition of critical thinking skills and tendencies (Seferoğlu \& Akbıyık, 2006, p. 98).

It is also important that the teacher offers students an environment where they can express their thoughts freely while performing these activities, as well as providing students with activities to improve their thinking skills. This environment should be a free environment where students can discuss different views and express their own views. In order to develop thinking skills in the educational environment, it is considered essential to develop discussion skills. Discussion is also an important technique for providing interaction between students and teachers. "Discussion-based teaching is a student-centered approach where students interact together and demonstrate their mental development. The discussion method has an important role in students' structuring knowledge and creating correct mental models." (Maden and Kaya, 2018, p. 70). At the same time, the discussion process will enable the students to go through different mental stages, compare the thoughts of others with their own thoughts, establish relationships between thoughts, and learn how the thinking processes work. In this process, there are certain rules that the teacher and the student should pay attention to. Güneş (2012, p. 142) explains these rules as follows: The teacher should start the discussion with small groups first and then continue with large groups. The way the teacher manages the discussion is important in the process. The teacher should not be in a position to make the final decision, check and approve all the answers, and ensure that the discussion ends in a desired manner. On the contrary, the teacher should provide an environment in which students express their thoughts freely, evaluate others' thoughts, where group interaction is maximized, and the discussion does not turn into a war or race of ideas. The teacher should keep the questioning environment alive in order to allow the establishment of a relationship between the information and to benefiting from other ideas. The environments that will activate the discussion skills in the education process should be qualified to enable students to think individually and discuss with their peers.

In order to develop thinking skills, teachers need to have developed critical thinking and discussion skills and therefore have a positive attitude towards the discussion. Because "the interaction of teachers and students in the discussion education carried out in schools, teachers' forming a good example by their attitudes and behaviors about the discussion activity affect the efficiency of the discussion education. Because students mostly determine their attitudes and behaviors in the classroom according to their teachers." (Yeşil, 2004, p. 204). Teacher candidates need to improve themselves in discussion and critical thinking during the teacher education process. "For this reason, it is important for academics to exhibit role model behaviors in the education process by taking care to create a classroom environment that is respectful to different ideas and tolerant to discussion and contradictions." (Can \& Kaymakç1, 2015, p. 81).

In the literature, there are studies which examine the attitudes, views, and behaviors of teacher candidates and teachers towards discussion and the effect of discussion skills on the text comprehension, 
language and critical thinking skills of students (Yeşil, 2003; Yeşil, 2004; Felton, 2005; Henning, 2008; Dallimore, Hertenstein \& Platt, 2008; Murphy, Wilkinson, Soter, Hennessey \& Alexander, 2009; Bunchanan, 2011; Cashin, 2011; Ocak \& Karakuş, 2015a; Maden \& Kaya, 2018; Ocak, Karakuş \& Ocak, 2018; Biney, 2018). Teacher candidates should have a positive attitude towards the discussion in order to develop a discussion environment in the educational environment and to improve their skills in managing this environment. When considered from this point of view, it is important to determine the attitudes of the teacher candidates towards the discussion. While there are studies in the literature on the discussion skills and attitudes of teacher candidates towards the discussion, there is no study that examines the attitudes of Turkish teacher candidates towards the discussion. Considering the relationship between thinking skills and language attitudes of Turkish teacher candidates towards discussion skills are thought to be important.

\subsection{Research questions}

In the study, where the attitudes of the Turkish teacher candidates towards the discussion skills were examined according to different variables, the answers to the following questions were sought:

1. Do Turkish teacher candidates' attitudes towards discussion differ according to gender?

2. Do Turkish teacher candidates' attitudes towards discussion differ according to grade?

3. Do Turkish teacher candidates' attitudes towards discussion differ according to the type of high school graduated?

4. Do Turkish teacher candidates' attitudes towards discussion differ according to the number of books read in one month?

\section{Method}

\subsection{Research design}

The screening model was used in the research. Screening models are research approaches that aim to describe a situation that exists in the past or present as it is (Karasar, 1999). In this study, it was tried to determine the attitudes of Turkish teacher candidates towards discussion skills according to grade level, gender, type of school, and the number of books read in a month.

\subsection{Participants}

The appropriate sampling method was used to determine the research sample. The appropriate sampling method is a method that prevents loss of time. The researcher creates a sample starting from the most accessible responders until they reach a group in dimension they need. (Büyüköztürk, K1lıçÇakmak, Akgün, Karadeniz \& Demirel, 2013, p. 92).

Participants of the study are the Turkish teacher candidate of Atatürk University, Kazım Karabekir Education Faculty, Turkish Language Education Department. A total of 253 Turkish teacher candidates, 55 of which were 1 st grade, 56 of which were 2 nd grade, 86 of which were 3 rd grade, and 56 of which were 4 th grade participated in the study.

\subsection{Data collection procedures}

To determine the attitudes of Turkish teacher candidates that constitute the sample of the research towards the discussion, the "Discussion Skills Attitude Scale" developed by Ocak and Karakuş (2015b) 
was used. The scale was composed of 20 items in a five-point Likert type. The expressions "I fully agree" (5) and "I agree" (4) were used for the positive items used in the scale, and "I fully disagree" (1) and "I disagree" (2) were used for the negative items. For items that do not contain a positive or negative opinion, the phrase "I am indecisive" (3) was used. The scale consists of three dimensions as "awareness", "impact" and "diffidence". Ten of the items in the scale report positive judgments, and ten report negative judgments. As a result of the analyses made in the last form of the scale, the lowest score that can be obtained is 20 , and the highest score is 100 . The reliability coefficient of this scale was determined as $r=.86$ at the end of the reliability study. It was concluded that the factor loads of the scale ranged between 0.59 and 0.76 , and the internal consistency coefficient (Cronbach alpha) value was $\alpha=$ 0.865 . Accordingly, it can be said that the scale subject to the research has a structure that can be used in terms of factor distributions and validity-reliability values.

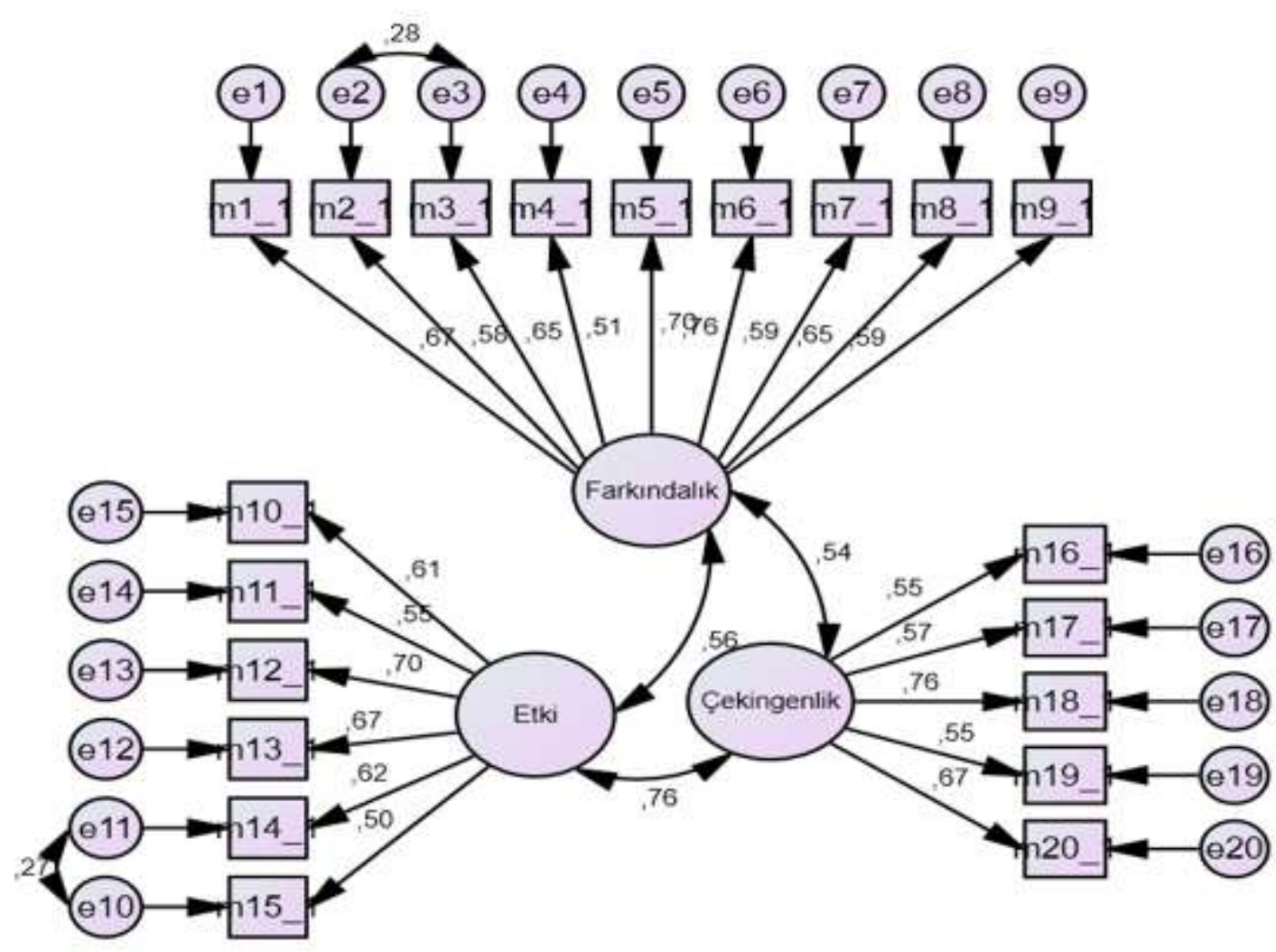

Figure 1: CFA Results

The fit indexes of the CFA and the reference ranges are shown in Table 1.

Table 1. The Fit Indexes of the CFA

\begin{tabular}{ccccc}
\hline \multirow{2}{*}{ Indexes } & \multicolumn{2}{c}{ Reference Value } & \multirow{2}{*}{ Measurement } & \multirow{2}{*}{ Result } \\
\cline { 2 - 3 } & Good Fit & Acceptable Fit & & \\
\hline CMIN/DF & $0<\chi 2 / \mathrm{sd} \leq 3$ & $3<\chi 2 / \mathrm{sd} \leq 5$ & 1.800 & Good Fit \\
TLI & $.95<\mathrm{TLI} \leq 1$ & $.90<\mathrm{TLI} \leq .94$ & .907 & Acceptable Fit \\
RMSEA & $0 \leq \mathrm{RMSEA} \leq .05$ & $.05 \leq \mathrm{RMSEA} \leq .08$ & .056 & Acceptable Fit \\
SRMR & $0 \leq \mathrm{SRMR} \leq .05$ & $0.05 \leq \mathrm{SRMR} \leq .10$ & .0586 & Acceptable Fit
\end{tabular}




\begin{tabular}{ccccc} 
CFI & $.95<\mathrm{CFI} \leq 1$ & $.90<\mathrm{CFI} \leq .94$ & .920 & Acceptable Fit \\
GFI & $.95<\mathrm{GFI} \leq 1$ & $.90<\mathrm{GFI} \leq .94$ & .90 & Acceptable Fit \\
$\mathrm{Sd}$ & & & 165 & \\
\hline
\end{tabular}

According to the CFA, the results are as follows: $\chi 2 / \mathrm{sd}=1,800$, RMSEA $=.056, \mathrm{SRMR}=.0586, \mathrm{CFI}=.92$, GFI $=.90, \mathrm{TLI}=.907$.

\subsection{Data analysis}

The data obtained were analyzed with the SPSS 22.0 package program. First of all, it was determined whether the data obtained from the attitude scale towards the discussion showed normal distribution. Shapiro-Wilk test, arithmetic mean, mode and median values, kurtosis and skew coefficients, Histogram Graph, Normal QQ Graph, Slope Free Normal QQ Graph, PP Graph, Box Graph and Trunk Leaf Diagram of the test were examined, it was decided that the data did not show normal distribution. Nonparametric Mann Whitney U and Kruskal Wallis Test were used in the analysis phase since the data did not meet the normality assumptions.

Mann Whitney U Test is used to investigate whether there is a significant difference between the ranks of the measurement results of two groups that are not related to each other (Kilmen, 2015, p. 224). This test is the non-parametric equivalent of the t-Test for Independent Samples. Mann Whitney U Test is generally used in experimental studies with a low sample size (Seçer, 2015, p. 201). The Kruskal Wallis Test is used to investigate whether there are significant differences between the measurements of more than two unrelated groups. The results obtained from the tests are tabulated and interpreted according to the $\mathrm{p}<0.05$ significance value.

\section{Results}

The results of the Mann Whitney U test, in which the attitudes of the Turkish teacher candidates towards the discussion are examined according to the gender variable, are given in Table 1.

Table 2. Results of Mann Whitney U test for Turkish teacher candidates' attitudes towards discussion according to gender variable

\begin{tabular}{llllll}
\hline Gender & $\mathrm{n}$ & $\bar{X}$ & $\mathrm{SD}$ & $\mathrm{U}$ & $\mathrm{p}$ \\
\cline { 1 - 3 } Female & 189 & 127.30 & 24060.50 & \multirow{2}{*}{5990.500} & \multirow{2}{*}{.909} \\
\cline { 1 - 4 } Male & 64 & 126.10 & 8070.50 & & \\
\hline
\end{tabular}

According to Table 1, the arithmetic mean scores showing the attitudes of the female Turkish teacher candidates towards the discussion is 127.30 , and it is 126.10 for the male Turkish teacher candidates. In this case, there was no significant difference between the attitudes of male and female teacher candidates towards discussion $(\mathrm{p}>.05)$.

The results of the Kruskal Wallis test, in which the attitudes of the Turkish teacher candidates towards the discussion are examined according to the grade level, are presented in Table 2. 
Table 2. Kruskal Wallis test results for Turkish teacher candidates' attitudes towards discussion according to grade level variable

\begin{tabular}{cccccc}
\hline Grade Level & $\mathrm{n}$ & Order Average & sd & $\boldsymbol{X}^{\mathbf{2}}$ & $\mathrm{p}$ \\
\hline 1 & 55 & 145.73 & 3 & 7.690 & .053 \\
2 & 56 & 132.64 & & & \\
3 & 86 & 111.73 & & & \\
4 & 56 & 126.41 & & &
\end{tabular}

In Table 2, it is seen that there is no significant difference between the attitudes of Turkish teacher candidates towards the discussion and their grade levels ( $p>.05$ ). Although there is no significant difference between the attitudes of the teacher candidates towards the discussion and the grade level, the average score of the Turkish teacher candidates at the 1st-grade level $(145,73)$ is higher than the average score of the Turkish teacher candidates at the $2 \mathrm{nd}$, 3rd and 4th-grade levels. At the same time, it can be said that as the grade level increases, the average score of Turkish teacher candidates decreases.

The results of the Kruskal Wallis test, in which the attitudes of the Turkish teacher candidates towards the discussion are examined according to the school type, are presented in Table 3.

Table 3. Kruskal Wallis test results for Turkish teacher candidates' attitudes towards discussion according to the variable of high school graduated

\begin{tabular}{|c|c|c|c|c|c|}
\hline School Type & $\mathrm{n}$ & $\begin{array}{c}\text { Order } \\
\text { Average }\end{array}$ & sd & $X^{2}$ & $\mathrm{p}$ \\
\hline Anatolian High School & 161 & 121.44 & 6 & 11.769 & .067 \\
\hline $\begin{array}{l}\text { Anatolian Teachers/Social Sciences } \\
\text { High School }\end{array}$ & 23 & 162.13 & & & \\
\hline Anatolian Imam Hatip High School & 9 & 103.33 & & & \\
\hline Imam Hatip High School & 18 & 132.58 & & & \\
\hline Normal High School & 21 & 143.55 & & & \\
\hline Vocational High School & 17 & 131.76 & & & \\
\hline Open Education High School & 4 & 56.13 & & & \\
\hline
\end{tabular}

In Table 3, it is seen that there is no significant difference between the attitudes of Turkish teacher candidates towards the discussion and the type of high school graduated ( $p>.05)$. Although there is no significant difference between the type of high school graduated and the attitude towards the discussion, the average score of Turkish teacher candidates who graduated from Anatolian Teacher-High School / Social Sciences High School $(162,13)$ is higher than those who graduated from other high school types.

The results of the Kruskal Wallis test to determine whether the attitudes of the Turkish teacher candidates towards discussion differ according to the average number of books read in a month are presented in Table 4. 
Table 4. Kruskal Wallis test results for Turkish teacher candidates' attitudes towards discussion according to the variable of the number of books read in a month

\begin{tabular}{lccccc}
$\begin{array}{l}\text { Number of } \\
\text { Books }\end{array}$ & $\mathrm{n}$ & Order Average & sd & $X^{2}$ & $\mathrm{p}$ \\
\hline $1-2$ & 114 & 111.61 & 3 & 9.585 & .022 \\
$3-4$ & 101 & 138.90 & & & \\
$5-6$ and more & 22 & 147.84 & & & \\
\hline
\end{tabular}

In Table 4, it is seen that there is a significant difference between the attitudes of Turkish teacher candidates towards the discussion and the average number of books read in a month $(\mathrm{p}<.05)$. Teacher candidates who read 5-6 books or more in a month have a higher average score (147.84) than the teacher candidates who read less. It can be said that as the number of books read in a month increases, the average score of attitudes towards the discussion increases.

\section{Discussion}

In this section, results related to the attitudes of Turkish teacher candidates towards discussion skills will be discussed according to variables of gender, grade level, type of high school graduated, and the number of books read in a month. Although there are studies in the literature that examine the attitudes of teacher candidates towards discussion skills in general, there is no study that specifically examines the attitudes of Turkish teachers. However, many studies have been conducted to examine the attitudes of teacher candidates and Turkish language teacher candidates towards critical thinking skills, for which discussion is one of the basic steps. Therefore, the results of the studies on attitudes towards critical thinking skills and the results of this study on attitudes towards discussion skills can be related. In this context, the results of the studies on the critical thinking tendencies and attitudes of teacher candidates were also benefited from in the discussion section.

It was concluded that the attitudes of Turkish teacher candidates towards discussion skills did not differ significantly according to gender. Similar results were obtained in studies examining the attitude towards critical thinking skills. Kürüm (2002), Özdemir (2005), Korkmaz (2009), Şen (2009), Ekinci and Aybek (2010), Bağcı and Şahbaz (2012) have reached the conclusion that gender does not make a significant difference in their studies of teacher candidates' critical thinking skills and tendencies. Ocak and Gürbüz (2015a), who examined the attitudes of teacher candidates towards discussion skills, found that gender did not make a significant difference in terms of total attitude, impact, and shyness towards the discussion, but it made a significant difference in favor of males in the dimension of awareness. Semerci (2003), Tümkaya (2011), and Emir (2012) stated that there was a significant difference in favor of male teacher candidates in the sub-dimensions in their study, where they examined critical thinking attitudes of teacher candidates. It can be said that this is due to the fact that there are more areas where males can socialize in social life and that social roles allow males to express their ideas more. In the study, it was found that gender did not make a significant difference in the discussion skills, but the average score of female teacher candidates $(127,30)$ is higher than the average score of male teacher candidates $(126,10)$. Çetinkaya (2011), Can and Kaymakçı (2015) found that there was a significant difference in favor of female teacher candidates in some sub-dimensions in their study, in which they examined the critical thinking attitudes of teacher candidates and their views towards critical thinking. In general, it is seen that gender is not effective in discussion and critical thinking skills, but it is effective 
in some sub-dimensions in some researches, sometimes in favor of male teacher candidates and sometimes in favor of female teacher candidates.

It was concluded that the attitudes of Turkish teacher candidates towards discussion skills did not make a significant difference according to the grade level. However, the average score of Turkish teacher candidates is 145.73 in the 1 st grade, 132.64 in the 2 nd grade, 111.73 in the 3 rd grade, and 126.41 in the 4th grade. Attitudes towards discussion skills are expected to increase as the grade level increases. However, when the average scores related to the grade level is analyzed, it is seen that the grade point average of Turkish teacher candidates decreases as the grade level increases. In the studies examining the attitudes of teacher candidates towards discussion skills, the grade level was not taken into consideration as a variable. Different results were obtained in the studies on critical thinking skills to which discussion skill is related. Çetinkaya (2011) stated in her study in which she examined the views of Turkish teacher candidates about critical thinking that critical thinking tendencies of $1^{\text {st }}$ graders were more positive than the 4th graders in total and in the sub-dimensions of analyticalness, openmindedness and seeking the truth and there was no significant difference in other sub-dimensions. Ekinci and Aybek (2010), Kürüm (2002), and Y1lmaz (2017), on the other hand, concluded that the critical thinking tendency does not make a significant difference according to the grade level. Zayif (2008), Can and Kaymakçı (2015) found that there was a significant difference between grade level and critical thinking skills in favor of $4^{\text {th }}$ grades. Yeşil (2004) stated that the discussion is a skill that can be learned and developed, and stated that the discussion education should be done by doing, by experiencing and by examining and observing the appropriate examples. In this context, students should be given the opportunity to have democratic discussions and have appropriate experiences in classrooms on lessons or social issues. The student should be able to use theoretical knowledge in the field of application. This also applies to discussion skills. The skill of discussion requires not only knowledge about discussion but also concrete experiences that will put this information into practice.

It is concluded that the attitudes of Turkish teacher candidates towards discussion skills do not make a significant difference according to the type of high school graduated. Nevertheless, the average score of teacher candidates graduated from Anatolian Teacher / Social Sciences High School (162.13) was found to be higher than those graduated from other high schools. Social Sciences High Schools are schools where verbal classes are more dominant, and discussions are at the forefront rather than knowledge transfer. The difference between the mean scores is thought to stem from this situation. In the study, they examined the attitudes of teacher candidates towards discussion skills, Ocak and Karakuş (2015) concluded that the type of high school graduated created a significant difference in total attitude and sub-dimensions of effect and shyness, but it did not create a significant difference in the subdimension of awareness. They also stated that teacher candidates who graduated from Anatolian High School and Super High School, which are at a higher level in terms of academic success, had a lower attitude towards the discussion. In the literature, there are studies determining that there is no significant relationship between the critical thinking skills of teacher candidates and the type of high school they graduated from. (Kürüm, 2002; Zayif, 2008; Şen, 2009; Çetinkaya, 2011; Can \& Kaymakçı, 2015; Aksu Demirtaş, 2019; Ergün, 2019).

It has been concluded that the attitudes of Turkish language teacher candidates towards discussion skills make a significant difference according to the average number of books they read in a month. This difference is in favor of teacher candidates who read 5-6 books or more in a month. In addition, it was seen that the attitudes of Turkish teacher candidates towards discussion skills increased in direct proportion with the number of books read. One of the most important achievements provided by reading is the development of the vocabulary. An individual with a developed vocabulary will use the language more effectively and will, therefore, develop himself/herself in the context of producing thoughts and using thinking skills. In the studies examining the attitude towards the discussion skill, variables such 
as the number of books read monthly or the habit of reading books were not included. In studies that examine critical thinking skills, studies, where the number of books read, makes a significant difference are found. Susar Kırmız1, Fenli, and Kasap (2014) examined the relationship between critical thinking skills of teacher candidates and reading habits and found a positive relationship. In their study, Şenyiğit (2016) and Polat (2017) concluded that there is a significant difference between the teacher candidates' critical thinking tendencies and the number of books read in favor of teacher candidates who read. There are also studies in the literature where there is no significant difference between critical thinking skills and the number of books read or reading habits (Şen, 2009; Ergün, 2019).

As a result, in the study in which it was examined whether the attitudes of Turkish language teacher candidates towards discussion skills differ according to different variables, no significant difference was found according to the variables of gender, grade level, and type of high school graduated. It was concluded that there was a significant difference between the attitudes of teacher candidates towards discussion skills and the number of books they read in a month.

\section{Conclusions}

It was concluded that the attitudes of the teacher candidates towards the discussion skill did not differ significantly according to gender, class level and high school variable they graduated from. It was determined that the attitudes of the Turkish teacher candidates towards the discussion skill showed a significant difference according to the number of books read in a month. As the number of books they read in one month increased, their attitudes towards discussion skills also increased. Based on these results, the following suggestions can be listed:

- It is important for teacher candidates to develop a positive attitude towards the discussion skill in order to improve the discussion skills of the students. In this context, environments, where teacher candidates can improve their discussion skills and apply their theoretical knowledge about discussion, should be created. In order for this to happen, faculty members teaching the teacher candidates should also include studies to improve their discussion skills.

- Experimental studies can be conducted to improve the discussion skills of teacher candidates. It can be investigated whether the use of discussion skills in the classroom environment has an impact on teacher candidates' attitudes towards discussion skills.

- In order to develop critical thinking skills, it should be taken into consideration that the skill and culture of discussion should be developed, and activities that will enable the realization of the importance of discussion should be planned at all teaching levels.

\section{Ethics Committee Approval}

The author(s) confirm(s) that the study does not need ethics committee approval according to the research integrity rules in their country. (Date of Confirmation: June 8, 2020)

\section{References}

Aksu-Demirtaş, A. (2019). Sosyal bilgiler öğretmen adaylarının eleştirel düşünme eğilim düzeyleri. (Unpublished master's thesis). Kastamonu University, Kastamonu, Türkiye. 
Bağc1, H. \& Şahbaz N. K. (2012). Türkçe öğretmeni adaylarının eleştirel düşünme beceriler üzerine bir değerlendirme. Mersin Üniversitesi Eğitim Fakültesi Dergisi, 8(1), 1-12.

Biney, I. K. (2018). Improving teaching and learning in higher education institutions: is discussion method the answer?. MIER Journal of Educational Studies, 8(2), 147-163.

Buchanan, L. B. (2011). Discussion in the elementary classroom: How and why some teachers use discussion. The Georgia Social Studies Journal, 1(1), 19-31.

Büyüköztürk, Ş., Kılıç Çakmak, E., Akgün, Ö. E., Karadeniz, Ş. \& Demirel, F. (2015). Bilimsel araştırma yöntemleri. (19 $\mathrm{ed}$.). Ankara: Pegem Akademi.

Can, Ş. \& Kaymakçı, G. (2015). Öğretmen adaylarının eleştirel düşünme eğilimleri. NWSA-Education Sciences, 10(2), 66-83.

Cashin, W. E. (2011). Effective classroom discussions. IDEA Paper, 49, 1 -5.

Çetinkaya, Z. (2011). Türkçe öğretmen adaylarının eleştirel düşünmeye ilişkin görüşlerinin belirlenmesi. Ahi Evran Üniversitesi Eğitim Fakültesi Dergisi, 12(3), 93-108.

Dallimore, E. J., Hertenstein, J. H. \& Platt, M. B. (2008). Using discussion pedagogy to enhance oral and written communication skills. College Teaching, 56(3), 163-172.

Ekinci, Ö. \& Aybek, B. (2010). Öğretmen adaylarının empatik ve eleştirel düşünme eğilimlerinin incelenmesi. Illkögretim Online, 9(2), 816-827.

Emir, S. (2012). Eğitim fakültesi öğrencilerinin eleştirel düşünme eğilimleri. Hasan Ali Yücel Eğitim Fakültesi Dergisi, 9(1), 34-57.

Ergün, A. (2019). Sinıf ögretmeni adaylarının eleştirel düsünme becerilerine ilişsin görüşlerinin incelenmesi (Erciyes Üniversitesi Örneği). (Unpublished master's thesis). Erciyes Univesity, Kayseri, Turkey.

Felton, M. K. (2005). Approaches to argument in critical thinking instruction. Thinking Classroom, 6(4), 6-13.

Güneş, F. (2012). Öğrencilerin düşünme becerilerini geliştirme. Türklük Bilimi Araştırmaları, 32, 127146.

Henning, E. J. (2008). The Art of Discussion Based Teaching. New York: Routledge.

Karasar, N. (1999). Bilimsel Araştırma Yöntemi. Ankara: Nobel Yayıncılık.

Kilmen, S. (2015). Eğitim araştırmacıları için spss uygulamalı istatistik. Ankara: Edge Akademi Yayınlar1.

Korkmaz, Ö. (2009). Öğretmenlerin eleştirel düşünme eğilim ve düzeyleri. Ahi Evran Üniversitesi Kırşehir Eğitim Fakültesi Dergisi, 10(1), 1-13.

Kurudayığlu, M. \& Çetin, Ö. (2015). Temel beceriler ve Türkçe öğretimi. Ana Dili Eğitimi Dergisi, 3(3), 1-19.

Kürüm, D. (2002). Öğretmen adaylarının eleştirel düşünme gücü. (Unpublished master's thesis). Anadolu University, Eskişehir, Turkey.

Maden, S. \& Kaya M. (2018). Bir iletişim biçimi ve öğretim şekli olarak tartışmaya dair öğretmen görüşleri. Iğdır Üniversitesi Sosyal Bilimler Dergisi, 14, 63-89. 
MEB. (2006). İlkögrretim Türkçe Dersi (6, 7, 8. Sinıflar) Öğretim Programı. Ankara: Devlet Kitapları Müdürlüğü.

Murphy, P. K., Wilkinson, I. A. G., Soter, A. O., Hennessey, N. Maeghan \& Alexander, J. F. (2009). Examining the effects of classroom discussion on students' comprehension of text: a meta-analysis. Journal of Educational Psychology, 101(3), 740-764.

Ocak, G. \& Karakuş, G. (2015a). Öğretmen adaylarının tartışma becerilerine yönelik tutumları. Trakya üniversitesi Sosyal Bilimler Dergisi, 17(2), 153-170.

Ocak, G. \& Karakuş, G. (2015b). Öğretmen adaylarının tartışma becerilerine ilişkin tutum ölçeği: bir ölçek geliştirme çalışması. Kuramsal Eğitimbilim Dergisi, 8(1), 50-69,

Ocak, G., Karakuş, G. \& Ocak İ. (2018). Öğretmen adaylarının tartışma becerileri ile iletişim becerileri arasındaki ilişkinin incelenmesi. Trakya Üniversitesi Sosyal Bilimler Dergisi, 20(1), 299-317.

Öner, N. (2001). Niçin felsefe?. In Betül Çotuksöken (Eds). Cumhuriyet Döneminde Türkiye'de Öğretim ve Araştırma Alanı Olarak Felsefe (pp. 432-436). Ankara: Türkiye Felsefe Kurumu.

Özdemir, S. (2005). Üniversite öğrencilerinin eleştirel düşünme becerilerinin çeşitli değişkenler açısından değerlendirilmesi. Türk Eğitim Bilimleri Dergisi, 3(3), 297-316.

Polat, M. (2017). Stnıf Öğretmenlerinin eleştirel düşünme eğilimleri ile yaratıcılık düzeylerinin bazı değişkenlere göre incelenmesi. (Unpublished master's thesis). Adıyaman University, Adıyaman, Turkey.

Seferoğlu, S. S. \& Akbıyık, C. (2006). Eleştirel düşünme ve öğretimi. Hacettepe Üniversitesi Eğitim Fakültesi Dergisi, 30, 193-200.

Seçer, İ. (2015). SPSS ve LISREL ile pratik veri analizi. Ankara: Anı Yayınc1lık.

Semerci, Ç. (2003). Eleştirel düşünme becerilerinin geliştirilmesi. Eğitim ve Bilim, 28(127), 64-70.

Susar-Kırmızı, F., Fenli, A. \& Kasap, D. (2014). Sınıf öğretmeni adaylarının eleştirel düşünme eğilimleri ile okuma alışkanlıklarına yönelik tutumları arasındaki ilişki. Uluslararası Türkçe Edebiyat Kültür Eğitim Dergisi, 3(1), 354-367.

Şen, Ü. (2009). Türkçe öğretmeni adaylarının eleştirel düşünme tutumlarının çeşitli değişkenler açısından değerlendirilmesi. Zeitschrift für die Welt der Türken/Journal of World of Turks, 1(2), 6989.

Şenyiğit, Ç. (2016). Sinıf öğretmeni adaylarının eleştirel düşünme eğilimlerinin ve kitap okuma alışkanlıklarına ilişkin tutumlarının çeşitli değişkenlere göre incelenmesi. (Unpublished master's thesis). Dokuz Eylül University, İzmir, Turkey.

Tümkaya, S. \& Aybek, B. (2008). Üniversite öğrencilerinin eleştirel düşünme eğilimlerinin sosyodemografik özellikler açısından incelenmesi. Çukurova Üniversitesi Sosyal Bilimler Enstitüsü Dergisi, 17(2), 387-402.

Tümkaya, S. (2011). Fen bilimleri öğrencilerinin eleştirel düşünme eğilimleri ve öğrenme stillerinin incelenmesi. Ahi Evran Üniversitesi Ĕ̈itim Fakültesi Dergisi, 12(3), 215-234.

Yeşil, R. (2003). Tartışma etkinliğine ilişkin öğrenci tutum ve davranışlarının değerlendirilmesi. Kuram ve Uygulama Ĕ̈itim Yönetimi, 36, 606-624.

Yeşil, R. (2004). Öğrenci ve öğretim elemanlarının tartışma tutum ve davranışları arasındaki ilişki. Gazi Üniversitesi Kırşehir Eğitim Fakültesi, 5(2), 195-208. 
Yılmaz, B. (2017). Sinıföğretmen adaylarının eleştirel düşünme ve yanal düşünme eğilimleri arasındaki iliş̧ki. (Unpublished master's thesis). Abant İzzet Baysal University, Bolu, Turkey.

Zayif, K. (2008). Öğretmen Adaylarının Eleştirel Düşünme Ĕgilimleri. (Unpublished master's thesis). Abant İzzet Baysal University, Bolu, Turkey.

\section{Türkçe öğretmeni adaylarının tartışmaya yönelik tutumları}

\section{$\ddot{O} z$}

$\mathrm{Bu}$ araştırmada Türkçe öğretmeni adaylarının tartışma becerilerine yönelik tutumlarını cinsiyet, sınıf düzeyi, mezun olunan lise ve bir ayda okunan kitap sayısı değişkenlerine göre belirlemek amaçlanmıştır. Araştırma örneklemi uygun örnekleme yöntemi ile belirlenmiş. Araştırmanın, söz konusu örnekleme yöntemiyle belirlenen, katılımcıları Atatürk Üniversitesi Kazım Karabekir Eğitim Fakültesi Türkçe Eğitimi Ana Bilim Dalı öğrencileridir. Çalışmaya 55 1. sınıf, 56 2. sınıf, 86 3. sınıf ve 56 4. sınıf olmak üzere toplam 253 öğrenci katılım sağlamıştır. Tarama modeli kullanılan araştırmada, Türkçe öğretmeni adaylarının tartışma becerilerine yönelik tutumlarını belirlemek için Ocak ve Karakuş (2015) tarafından geliştirilen "Tartışma Becerisi Tutum Ölçeği” kullanılmıştır. Elde edilen veriler SPSS 22.0 paket programı ile analiz edilmiştir. Sonuç olarak Türkçe öğretmeni adaylarının tartışma becerilerine yönelik tutumlarının cinsiyet, sınıf düzeyi ve mezun olunan lise değişkenine göre farklılaşmadığı; bir ayda okunan kitap sayısına göre 5-6 ve üzeri kitap okuyanların lehine farklılaştığı görülmüştür. Çalı̧̧manın sonuçları, tartışma becerisine yönelik tutumları inceleyen çalışmalarla birlikte tartışılmıştır. Aynı zamanda tartışma becerisi, eleştirel düşünme becerisinin gelişiminde önemli bir yere sahip olduğu için eleştirel düşünme becerisine yönelik tutumları inceleyen çalışmaların sonuçları da tartı̧ma bölümünde dikkate alınmıştır.

Anahtar sözcükler: tartışma becerisi; Türkçe öğretmeni adayları; tutum; temel beceriler

\section{AUTHOR BIODATA}

Zeynep Cin Şeker completed her doctorate at Atatürk University, Faculty of Education, Department of Turkish Education. Her research interests include Turkish education and reading education. Currently, he is a faculty member at Atatürk University, Kâzım Karabekir Education Faculty, Turkish Education Department. 